\title{
Evaluating the sustainability of free water surface flow constructed wetlands: methane and nitrous oxide emissions
}

Haiming $\mathrm{Wu}^{a, b}$, Jian Zhang ${ }^{b *}, \mathrm{Huu} \mathrm{Hao} \mathrm{Ngo}^{c}$, Wenshan Guo ${ }^{c}$, Shuang Liang ${ }^{b}$

College of Natural Resources and Environment, Northwest A\&F University, Yangling, Shaanxi 712100, China

${ }^{b}$ Shandong Key Laboratory of Water Pollution Control and Resource Reuse, School of Environmental Science \& Engineering, Shandong University, Jinan 250100, PR China

${ }^{c}$ School of Civil and Environmental Engineering, University of Technology Sydney, Broadway, NSW 2007, Australia

\section{Abstract}

Constructed wetlands (CWs) have been used as a green technology to treat various wastewaters for several decades, and greenhouse gases production in these systems attracted increasing attention considering the contributions of methane and nitrous oxide emissions to global warming. However, the detailed knowledge about the contribution of CWs to methane and nitrous oxide emissions in treating sewage treatment plant effluent are still limited in particular for a better understanding of the sustainability of CWs. The fluxes of methane $\left(\mathrm{CH}_{4}\right)$ and nitrous oxide $\left(\mathrm{N}_{2} \mathrm{O}\right)$ from free water surface (FWS) CWs in northern China were measured continuously using the static-stationary chamber technique from 2012 to 2013 . The results showed that CWs were the significant source of $\mathrm{CH}_{4}$ and $\mathrm{N}_{2} \mathrm{O}$ emissions. Average emission rates of $\mathrm{CH}_{4}$ and $\mathrm{N}_{2} \mathrm{O}$ ranged from $-30.2 \mu \mathrm{g} \mathrm{m}^{-2} \mathrm{~h}^{-1}$ to $450.9 \mu \mathrm{g} \mathrm{m}^{-2} \mathrm{~h}^{-1}$, and $-58.8 \mu \mathrm{g} \mathrm{m}^{-2} \mathrm{~h}^{-1}$ to $1251.8 \mu \mathrm{g} \mathrm{m}^{-2} \mathrm{~h}^{-1}$, respectively. Obvious annual and seasonal variations of $\mathrm{CH}_{4}$ and $\mathrm{N}_{2} \mathrm{O}$ emissions were observed over the 2-year period. In addition, temperatures and 
plant species had an impact on $\mathrm{CH}_{4}$ and $\mathrm{N}_{2} \mathrm{O}$ emissions. The obtained results showed that FWS CWs, improving water quality but emitting lower $\mathrm{CH}_{4}$ and $\mathrm{N}_{2} \mathrm{O}$, could be the alternative method for sewage treatment plant effluent.

Keywords: Constructed wetlands; Methane; Nitrous oxide; Wastewater treatment

\section{Introduction}

Over the last few decades, point and non-point pollution from agricultural, fishing, municipal and industrial drainage has become a worldwide environmental issue, especially in developing countries (Wu et al., 2015). On the one hand, untreated wastewater is directly discharged into continental surface waters because large scale municipal wastewater treatment plants (WWTPs) have not been constructed or fully operated due to large capital investments and operating costs in rural areas. Furthermore, considering the stringent discharge guidelines and standards, conventional wastewater treatment processes fail to remove large amount of nutrients efficiently, and are also not specifically designed to eliminate micropollutants (Luo et al., 2014; Kong et al., 2015; Lu et al., 2016; Wu et al., 2016). Consequently, untreated wastewater and sewage effluent which contain a variety of excessive organics and nutrients are discharged into rivers, estuaries and oceans, and may deteriorate the water environment quality and impact aquatic ecosystem health. Thus, the potential cost-effective treatment technologies of sewage/wastewater have been partially investigated in previous studies (Wu et al., 2011; Huang et al., 2013; Eveborn et al., 2014; Pan et al., 2016).

In recent years, constructed wetlands (CWs), as a green wastewater treatment technology by simulating natural wetlands, have been proven to be an effective alternative for conventional wastewater treatment technologies owing to their lower 
cost, less operation and maintenance requirements, and little reliance on energy inputs (Vymazal, 2011; Wu et al., 2015). CWs are generally comprised of vegetation, substrates, soils, microorganisms and water, and have been found to be able to remove various pollutants (e.g., organics, nutrients and micropollutants) from wastewater by utilizing a variety of physical, chemical, and biological mechanisms (microbial degradation, plant uptake, sorption, sedimentation, filtration and precipitation etc.) (Vymazal, 2011; Saeed and Sun, 2012; Wu et al., 2015). Such natural-like systems can be mainly divided into free water surface (FWS) and subsurface flow (SSF) CWs, and are usually used to treat different wastewaters such as domestic sewage, industrial drainage, urban and agricultural, stormwater runoff, animal wastewaters, leachates, mine drainage and polluted river water (Rai et al., 2013; Li et al., 2014; Vymazal, 2014; Greenway, 2015; Saumya et al., 2015). In addition, CWs might be utilized as a supplement to the existing conventional WWTPs for reclaiming and reusing the sewage effluent (Greenway, 2005; Rai et al., 2013). However, with the aim of improving the water quality and conserving aquatic ecosystem, little attention has been paid to purification of WWTPs effluent which was characterized by relatively low organic content and moderate nitrogen and phosphorous concentrations. Meanwhile, as an artificial ecological system simulating natural wetlands, greenhouse gases (GHG) production in these systems attracted increasing attention considering the contributions of methane $\left(\mathrm{CH}_{4}\right)$ and nitrous oxide $\left(\mathrm{N}_{2} \mathrm{O}\right)$ emissions to global warming (Kong et al., 2016). Compared to natural wetlands, heavy nutrient loading to CWs stimulates bacterial processing, resulting in higher fluxes of $\mathrm{CH}_{4}$ and $\mathrm{N}_{2} \mathrm{O}$, and thus $\mathrm{CWs}$ might be significant sources of $\mathrm{CH}_{4}$ and $\mathrm{N}_{2} \mathrm{O}$ emissions. Many studies investigated the emission of $\mathrm{CH}_{4}$ and $\mathrm{N}_{2} \mathrm{O}$ in various types of CWs for treating various kinds of wastewaters (such as domestic wastewater, dairy 
farm wastewater, municipal wastewater and mining runoff) based on the lab-scale and full-scale experiments (Tanner et al., 1997; Mander et al., 2008; Van der Zaag et al., 2010; Mander et al., 2014). From the current literature review by Mander et al. (2014), it indicated that average values of $\mathrm{CH}_{4}$ and $\mathrm{N}_{2} \mathrm{O}$ emissions in various types of $\mathrm{CWs}$ are $97-142 \mathrm{mg} \mathrm{m}^{-2} \mathrm{~h}^{-1}$ and 2.2-3.1 $\mathrm{mg} \mathrm{m}^{-2} \mathrm{~h}^{-1}$, and can be influenced by various physical, hydrological and operational factors such as dissolved oxygen (DO), hydraulic retention time (HRT), water depth, inflow loading, influent $\mathrm{C} / \mathrm{N}$ ratio, climate and vegetation. Therefore, in order to comprehensively evaluate the environmental benefit of using CWs as a sustainable wastewater treatment technology, a continuous measurement of $\mathrm{CH}_{4}$ and $\mathrm{N}_{2} \mathrm{O}$ emissions in treatment processes from $\mathrm{CWs}$ is absolutely necessary. Moreover, the detailed knowledge about the contribution of CWs to $\mathrm{CH}_{4}$ and $\mathrm{N}_{2} \mathrm{O}$ emissions in treating WWTPs effluent would be required in particular for the potential of GHG mitigation.

The aim of this work was to quantify the long-term $\mathrm{CH}_{4}$ and $\mathrm{N}_{2} \mathrm{O}$ emissions from $\mathrm{FWS}$ CWs for treating sewage treatment plant effluent. Annual and seasonal variations of $\mathrm{CH}_{4}$ and $\mathrm{N}_{2} \mathrm{O}$ emissions were analyzed over an approximate 2-year period. The $\mathrm{CH}_{4}$ and $\mathrm{N}_{2} \mathrm{O}$ fluxes and their global warming potential were further comparatively compared with common CW treatments and current WWTPs.

\section{Material and methods}

\subsection{Experimental system and operation}

Experimental FWS CW systems which were built in Baihua Park in Jinan, northern China $\left(36^{\circ} 40^{\prime} 36^{\prime \prime} \mathrm{N}, 117^{\circ} 03^{\prime} 42^{\prime \prime} \mathrm{E}\right)$ were designed to treat the effluent of sewage treatment plant (Figure 1). The climate of the area is characterized by a warm-temperature monsoonal climate. The experimental treatment system consisted 
of twelve FWS CW systems with a surface area of approximately $0.13 \mathrm{~m}^{2}(50 \mathrm{~cm}$ in depth and $40 \mathrm{~cm}$ in diameter), and each system had an outlet at the bottom. All CW system were filled with washed river sand (particle size $<2 \mathrm{~mm}, 0.39$ porosity) as the substrate with a depth of $25 \mathrm{~cm}$. Nine of $\mathrm{CW}$ systems were planted with three macrophyte species (W1: Phragmites australis, W2: Cyperus rotundus, W3: Zizania caduciflora) with three duplicates, and three of CW systems were not planted (U4: control). The density of plants was 12,20 and 20 rhizomes per system for W1, W2 and W3, respectively. Each system held $20 \mathrm{~L}$ water when filled. The water depth of each system was approximately $10 \mathrm{~cm}$ from the sand surface.

All experimental CW systems were operated for a period of approximate two years (from April 2012 to December 2013). The synthetic sewage treatment plant effluent was used as influent in each wetland in this study, The synthetic wastewater was prepared from tap water and mainly composed of sucrose, $\left(\mathrm{NH}_{4}\right)_{2} \mathrm{SO}_{4}, \mathrm{KH}_{2} \mathrm{PO}_{4}$ and $\mathrm{KNO}_{3}$ based on Grade I treatment standard of municipal sewage treatment plants in China (Wu et al., 2011). Specially, the characteristics of the influents in the present study were COD $72.71 \mathrm{mg} \mathrm{L}^{-1}, \mathrm{NH}_{4}{ }^{+}-\mathrm{N} 8.36 \mathrm{mg} \mathrm{L}^{-1}$, TN $21.14 \mathrm{mg} \mathrm{L}^{-1}$ and TP $8.36 \mathrm{mg}$ $\mathrm{L}^{-1}$, respectively. Sequencing fills-and-draw batch mode was applied to influent in the whole experimental period. The HRT was $10 \mathrm{~d}$ from April to November and $15 \mathrm{~d}$ in November and March when temperature was low.

\subsection{Sampling and analysis}

\subsubsection{Environmental parameters}

The following environmental parameters and climatic data in the experimental site were recorded: air temperature $\left({ }^{\circ} \mathrm{C}\right)$ and relative humidity $(\%)$. 


\subsubsection{Water sampling and analysis}

Water samples of influent and effluent were taken to evaluate their treatment performance. According to standard methods (APHA, 2005), and all samples were transferred immediately to the lab and analyzed immediately for the following water physicochemical parameters: chemical oxygen demand (COD; HACH DR $2008^{\mathrm{TM}}$ Spectrophotometer, USA), ammonia nitrogen $\left(\mathrm{NH}_{4}{ }^{+}-\mathrm{N}\right)$, total nitrogen (TN) and total phosphorus (TP). Dissolved oxygen (DO) and pH were measured in situ by a DO meter (HQ 30d 53LED ${ }^{\mathrm{TM}} \mathrm{HACH}, \mathrm{USA}$ ) and a glass pH meter (SG2-T SevenGo pro ${ }^{\mathrm{TM}}$ MTD, Switzerland).

\subsubsection{Gas sampling and analysis}

$\mathrm{CH}_{4}$ and $\mathrm{N}_{2} \mathrm{O}$ fluxes from the FWS CWs have been investigated in this study. Gas sampling was done using the static-stationary chamber every two days during the whole experimental period. The transparent chamber system $(50 \mathrm{~cm} \times 50 \mathrm{~cm} \times 50$ $\mathrm{cm}$ )was made of polymethyl methacrylate, and the details of collecting steps of gas samples were according to the method described in the previous studies (Wu et al., 2009). The $\mathrm{N}_{2} \mathrm{O}$ concentration was determined using the gas chromatography (SP-3410, China) with an electron capture detector (ECD) and a Poropak Q column, using $30 \mathrm{~mL} / \mathrm{min}$ high-purity nitrogen as the carrier gas. The temperature of the detector and column were set at $36{ }^{\circ} \mathrm{C}$ and $50{ }^{\circ} \mathrm{C}$, respectively. The $\mathrm{CH}_{4}$ concentration was determined using the gas chromatography (SP-6890, China) equipped with a flame ionization detector (GC-FID) and stainless steel packed columns (GDX502). The operating conditions for the GC were: $375{ }^{\circ} \mathrm{C}$ reformer temperature, $40{ }^{\circ} \mathrm{C}$ oven temperature and $200{ }^{\circ} \mathrm{C}$ detector temperature. The carrier gas was ultra-high purity $\mathrm{N}_{2}\left(30 \mathrm{~mL} \mathrm{~min}^{-1}\right) . \mathrm{CH}_{4}$ and $\mathrm{N}_{2} \mathrm{O}$ fluxes $\left(\mu \mathrm{g} \mathrm{m}^{-2} \mathrm{~h}^{-1}\right)$ were 
determined from the increase in concentration in the chambers over time with linear regression analysis according to the method described in the previous studies (Wu et al., 2009).

\subsection{Statistical analysis}

Statistical analyses were performed through the software SPSS 11.0 (SPSS Inc., Chicago, USA). A two independent samples t-test was conducted to determine the significance of differences between means. In all tests, differences and correlations were considered statistically significant when $\mathrm{P}<0.05$.

\section{Results and discussion}

\subsection{Environmental variables and water characteristics}

As shown in Figure 2, monthly mean air temperature during the whole monitoring period ranged from $2.1{ }^{\circ} \mathrm{C}$ to $29.5{ }^{\circ} \mathrm{C}$, and the annual average air temperature in 2012 was $21.4{ }^{\circ} \mathrm{C}$, which was slightly higher than that in $2013\left(19.1{ }^{\circ} \mathrm{C}\right)$. Moreover, the maximum temperature was observed to appear from May to August, and the minimum temperature was recorded in January and February. The average relative humidity during the study period was $57.4 \%$, with the higher value in the first year (59.6\%) and the lower value in the second year (55.6\%). The average effluent concentrations of COD, $\mathrm{NH}_{4}{ }^{+}-\mathrm{N}, \mathrm{TN}$ and TP in different FWS CW systems in the present study were $16.7-24.6 \mathrm{mg} \mathrm{L}^{-1}, 0.5-4.4 \mathrm{mg} \mathrm{L}^{-1}, 3.2-11.7 \mathrm{mg} \mathrm{L}^{-1}$ and $0.5-1.1 \mathrm{mg}$ $\mathrm{L}^{-1}$, respectively. These results indicated a significant improvement in water quality of sewage treatment plant effluent by treatment through FWS CWs. However, the average removal performance of the planted FWS CW systems was higher than that of unplanted CW systems, which suggested that there was a positive correlation 
among water purification and plant growth and establishment. On the whole, our results are consistent with other research which reported that reduction of pollutants was found to increase with growth and establishment of the plants (Rai et al., 2013).

\subsection{Variation of $\mathrm{CH}_{4}$ emission}

The variation of $\mathrm{CH}_{4}$ emission from different FWS CW systems in 2012-2013 is shown in Figure 3a. Average $\mathrm{CH}_{4}$ fluxes had obvious annual and seasonal variations in different FWS CWs, and ranged from $-30.2 \mu \mathrm{g} \mathrm{m}^{-2} \mathrm{~h}^{-1}$ to $450.9 \mathrm{\mu g} \mathrm{m}^{-2} \mathrm{~h}^{-1}$. Specially, the average $\mathrm{CH}_{4}$ flux in $\mathrm{CW}$ systems in the second year $\left(138.6 \mu \mathrm{g} \mathrm{m}^{-2} \mathrm{~h}^{-1}\right)$ was significantly higher than that $\left(88.6 \mu \mathrm{g} \mathrm{m}^{-2} \mathrm{~h}^{-1}\right)$ measured in the first year. The higher flux of $\mathrm{CH}_{4}$ was observed in summer compared to spring and fall, and a general seasonal peak occurred at the end of the summer/beginning of fall. However, it should be noted that the weak absorption (the sink) of $\mathrm{CH}_{4}$ was found in cold season (November and December) compared with other period when wetland became a source of $\mathrm{CH}_{4}$. These results suggested that seasons might have a significant effect on $\mathrm{CH}_{4}$ emissions in FWS CW systems. These results can also be illustrated by the line regression relationship between $\mathrm{CH}_{4}$ fluxes and air temperature. As shown in Figure $3 b$, during the 2-year monitoring period, the rate of $\mathrm{CH}_{4}$ emission in $\mathrm{CW}$ systems was significantly associated with air temperatures, and $\mathrm{CH}_{4}$ flux generally increased with the temperature rising. However, clear difference was found between vegetation and non-vegetation systems. The possible reason may be that microbial activity in CWs would increase with the increasing of temperature at a certain climatic condition (Wu et al., 2011; Mander et al., 2014). On the other hand, it is well recognized that temperature affects plant photosynthesis and plant biomass directly, and thus increases organic matter and gas transportation, which would give a positive 
effect on $\mathrm{CH}_{4}$ emission (Zhao et al., 2016). However, some other studies have reported negative effect of plant biomass on $\mathrm{CH}_{4}$ emission, and these impacts on $\mathrm{CH}_{4}$ emission from CWs vary significantly among plant species (Bhullar et al., 2014). Specifically, significant difference of $\mathrm{CH}_{4}$ emission rate was found among different CWs with various plant species in this study. The wetlands (W1) vegetated with Phragmites australis emitted higher $\mathrm{CH}_{4}\left(164.1 \mu \mathrm{g} \mathrm{m}^{-2} \mathrm{~h}^{-1}\right)$ than wetlands (W3) planted with Zizania caduciflora $\left(152.1 \mathrm{\mu g} \mathrm{m}^{-2} \mathrm{~h}^{-1}\right)$, following by and the wetlands (W2) with Cyperus rotundus (104.5 $\mathrm{\mu g} \mathrm{m}^{-2} \mathrm{~h}^{-1}$ ) throughout experimental period. Similarly, Zhao et al. (2016) studied the effects of plant diversity on $\mathrm{CH}_{4}$ emission and nitrogen removal, and concluded that the best combination of low $\mathrm{CH}_{4}$ emission and high $\mathrm{N}$ removal rates could be achieved in $\mathrm{CW}$ microcosms planting $P$. arundinacea. These results about difference among various plant species suggested that $\mathrm{CH}_{4}$ emission could be affected by other various factors such as CW type, oxygen level, inflow loading and C/N ratio (Mander et al., 2014; Zhao et al., 2016).

On the whole, analysis of $\mathrm{CH}_{4}$ emission in two years showed $\mathrm{FWS} \mathrm{CW}$ systems were a $\mathrm{CH}_{4}$ source, but the mean $\mathrm{CH}_{4}$ emission rate measured in this study were lower than the values $\left(0.2-36 \mathrm{mg} \mathrm{m}^{-2} \mathrm{~h}^{-1}\right)$ in FWS CW treatment systems and the values (0.064-23 $\mathrm{mg} \mathrm{m}^{-2} \mathrm{~h}^{-1}$ ) in SSF CWs reported in the literature (Mander et al., 2014), and as high as the values $\left(0.003-6.2 \mathrm{mg} \mathrm{m}^{-2} \mathrm{~h}^{-1}\right)$ in enhancing $\mathrm{CW}$ systems such as aerated CWs (Maltais-Landry et al., 2009). $\mathrm{CH}_{4}$ emission was also found to be significantly lower than the results $\left(0.61-9.7 \mathrm{mg} \mathrm{m}^{-2} \mathrm{~h}^{-1}\right)$ from natural wetlands (Chen et al., 2013). Moreover, when compared with common WWTPs, the emission rate was greatly lower than the values $\left(0.06-978 \mathrm{~g} \mathrm{~m}^{-2} \mathrm{~d}^{-1}\right)$ obtained among different processing units in the typical conventional WWTPs (Ren et al. 2015). 


\subsection{Variation of $\mathrm{N}_{2} \mathrm{O}$ emission}

The variation of $\mathrm{N}_{2} \mathrm{O}$ emission from $\mathrm{FWS} \mathrm{CW}$ systems during the experimental period is illustrated in Figure 4a. It is shown that $\mathrm{N}_{2} \mathrm{O}$ emission from the planted and unplanted wetlands varied annually and seasonally. The $\mathrm{N}_{2} \mathrm{O}$ emission rate ranged from $-58.8 \mu \mathrm{g} \mathrm{m}^{-2} \mathrm{~h}^{-1}$ to $1251.8 \mu \mathrm{g} \mathrm{m}^{-2} \mathrm{~h}^{-1}$, and specially, the average $\mathrm{N}_{2} \mathrm{O}$ flux in $\mathrm{CW}$

systems in $2013\left(381.8 \mathrm{\mu g} \mathrm{m}^{-2} \mathrm{~h}^{-1}\right)$ was significantly higher than that $\left(311.1 \mathrm{\mu g} \mathrm{m}^{-2} \mathrm{~h}^{-1}\right)$ recorded in 2012. This result indicated that the wetlands plants were well developed in the second year, and flourishing plants and active microbial population beneficial to nitrification and denitrification would promote production and transport of $\mathrm{N}_{2} \mathrm{O}$ as compared with in the initial first year. The $\mathrm{N}_{2} \mathrm{O}$ emission was also observed to be higher in summer than in spring and fall, and there had a lower $\mathrm{N}_{2} \mathrm{O}$ emission rate in winter due to the plants withering and microorganism activity decreasing. This result indicated that temperature had an important effect on the $\mathrm{N}_{2} \mathrm{O}$ emission in $\mathrm{CWs}$, which is in agreement with other reports (Zhang et al. 2005). Figure 4b presents the polynomial regression relationship between $\mathrm{N}_{2} \mathrm{O}$ emission rates and air temperature during the 2-year operating period. It can be illustrated that the $\mathrm{N}_{2} \mathrm{O}$ emission rate in CWs was increased with the rising temperatures, but the statistics was not significant. Mander et al. (2014) reported that the higher temperature of the environment slightly increased $\mathrm{CH}_{4}$ emission in $\mathrm{CWs}$, whereas in terms of $\mathrm{N}_{2} \mathrm{O}$ emission the relationship was insignificant and unclear.

The average $\mathrm{N}_{2} \mathrm{O}$ emission rate from the different wetlands in the whole experiment also varied each other. The planted wetlands had higher $\mathrm{N}_{2} \mathrm{O}$ emission rate than the unplanted wetlands, which indicated that the plant species had an impact on $\mathrm{N}_{2} \mathrm{O}$ emission. $\mathrm{N}_{2} \mathrm{O}$ emission rates from the planted wetlands also varied among plant 
species because of the relative differences in intrinsic species, possible ecotype and growth characteristics. On the whole, wetlands (W1) vegetated with Phragmites australis had highest $\mathrm{N}_{2} \mathrm{O}$ fluxes (mean value $514.2 \mu \mathrm{g} \mathrm{m}^{-2} \mathrm{~h}^{-1}$ ) following by wetlands (W3) planted with Zizania caduciflora (mean value $334.9 \mathrm{\mu g} \mathrm{m}^{-2} \mathrm{~h}^{-1}$ ) and the wetlands (W2) with Cyperus rotundus (mean value $328.2 \mu \mathrm{g} \mathrm{m}^{-2} \mathrm{~h}^{-1}$ ). The results suggested that FWS CW systems were a source of $\mathrm{N}_{2} \mathrm{O}$ throughout experimental period when treating sewage treatment plant effluent. The maximum $\mathrm{N}_{2} \mathrm{O}$ emission rates measured in this study were higher than the values $\left(50 \mu \mathrm{g} \mathrm{m}^{-2} \mathrm{~h}^{-1}\right)$ in natural ecosystems reported by Saggar et al. (2007), but lower than the values measured in CWs treating wastewater (2145 $\left.\mathrm{mg} \mathrm{m}^{-2} \mathrm{~h}^{-1}\right)$ reported by Wu et al. (2009), and still greatly lower than the values $\left(2 \times 10^{3} \mathrm{mg} \mathrm{m}^{-2} \mathrm{~h}^{-1}\right)$ measured in sewage treatment plants (Benckiser et al. 1996).

\section{Conclusions}

In this study, $\mathrm{CH}_{4}$ and $\mathrm{N}_{2} \mathrm{O}$ emissions from $\mathrm{FWS} \mathrm{CWs}$ treating sewage treatment plant effluent, ranging from $-30.2 \mu \mathrm{g} \mathrm{m}^{-2} \mathrm{~h}^{-1}$ to $450.9 \mu \mathrm{g} \mathrm{m}^{-2} \mathrm{~h}^{-1}$, and $-58.8 \mu \mathrm{g} \mathrm{m}^{-2} \mathrm{~h}^{-1}$ to $1251.8 \mu \mathrm{g} \mathrm{m}^{-2} \mathrm{~h}^{-1}$, respectively, were significantly low compared with traditional WWTPs, but obvious temporal variations were found in different FWS CWs. The average emission rates of $\mathrm{CH}_{4}$ and $\mathrm{N}_{2} \mathrm{O}$ in $\mathrm{CWs}$ in the second year $\left(138.6 \mu \mathrm{g} \mathrm{m}^{-2} \mathrm{~h}^{-1}\right.$ and $\left.381.8 \mu \mathrm{g} \mathrm{m}^{-2} \mathrm{~h}^{-1}\right)$ were significantly higher than that in the first year $\left(88.6 \mu \mathrm{g} \mathrm{m}^{-2}\right.$ $\mathrm{h}^{-1}$ and $311.1 \mu \mathrm{g} \mathrm{m}^{-2} \mathrm{~h}^{-1}$ ), and the higher fluxes of $\mathrm{CH}_{4}$ and $\mathrm{N}_{2} \mathrm{O}$ were observed in summer compared to spring and fall. The rate of $\mathrm{CH}_{4}$ and $\mathrm{N}_{2} \mathrm{O}$ emission was increased as the temperature rising, and the planted wetlands had higher $\mathrm{CH}_{4}$ and $\mathrm{N}_{2} \mathrm{O}$ emission than the unplanted wetlands. These results showed that $\mathrm{FWS}$ CWs, achieving the better treatment performance and lower GHG emission, could be an 
alternative method for sewage treatment plant effluent, which would be beneficial for the sustainable operation and successful application of CW systems.

\section{Acknowledgements}

We gratefully acknowledge financial support by the CRSRI Open Research Program (CKWV2015240/KY), National Science Foundation of China (NSFC, Project No. 51508466, 51578321), and the Fundamental Research Funds for the Central Universities (No. 2452016067).

\section{References}

1. APHA, 2005. Standard methods for the examinations of water and wastewater, 21st ed. APHA and AWWA and WEF DC, Washington.

2. Barbera, A.C., Borin, M., Ioppolo, A., Cirelli, G.L., Maucieri, C., 2014. Carbon dioxide emissions from horizontal sub-surface constructed wetlands in the Mediterranean Basin. Ecol. Eng. 64, 57-61.

3. Benckiser, G., Eilts, R., Linn, A., Lorch, HJ, Sümer, E., Weiske, A., Wenzhöfer, F., 1996. $\mathrm{N}_{2} \mathrm{O}$ emissions from different cropping systems and from aerated, nitrifying and denitrifying tanks of a municipal waste water treatment plant. Biol Fert Soils, 23, 257-265.

4. Chen, H., Zhu, Q., Peng, C., Wu, N., Wang, Y., Fang, X., Jiang, H., Xiang, W., Chang, J., Deng, X., Yu, G., 2013. Methane emissions from rice paddies natural wetlands, and lakes in China: synthesis and new estimate. Glob Chang Biol. 19, 19-32.

5. Eveborn, D., Gustafsson, J.P., Elmefors, E., Yu, L., Eriksson, A.K., Ljung, E., Renman, G., 2014. Phosphorus in soil treatment systems: accumulation and mobility. Water Res. 64, 42-52. 
6. Greenway, M., 2005. The role of constructed wetlands in secondary effluent treatment and water reuse in subtropical and arid Australia. Ecol. Eng. 25, 501-509.

7. Greenway, M., 2015. Stormwater wetlands for the enhancement of environmental ecosystem services: case studies for two retrofit wetlands in Brisbane, Australia. J. Clean. Prod. doi:10.1016/j.jclepro.2015.12.081

8. Huang, J.C., Suárez, M.C., Yang, S.I., Lin, Z.Q., Terry, N., 2013. Development of a constructed wetland water treatment system for selenium removal: incorporation of an algal treatment component. Environ Sci Technol. 47, 10518-10525.

9. Kong, Q., Wang, Z., Li, S., Miao, M., 2015. Characterization of the extracellular polymeric substances and microbial of aerobic granulation sludge exposed to cefalexin. Int. Biodeterior. Biodegrad. 102, 375-382.

10. Kong, Q., Wang, Z., Niu, P., Miao, M., 2016. Greenhouse gas emission and microbial community dynamics during simultaneous nitrification and denitrification process. Bioresour Technol. 210, 94-100.

11. Li, F., Lu, L., Zheng, X., Ngo, H.H., Liang, S., Guo, W., Zhang, X., 2014. Enhanced nitrogen removal in constructed wetlands: effects of dissolved oxygen and step-feeding. Bioresour Technol. 169, 395-402.

12. Lu, S., Zhang, X., Wang, J., Pei, L., 2016. Impacts of different media on constructed wetlands for rural household sewage treatment. J. Clean. Prod. 127, $325-330$

13. Luo, Y., Guo, W., Ngo ,H.H., Nghiem, L.D., Hai, F.I., Zhang, J., Liang, S., Wang, X.C., 2014. A review on the occurrence of micropollutants in the aquatic environment and their fate and removal during wastewater treatment. Sci Total Environ. 473-474, 619-641. 
14. Maltais-Landry, G., Maranger, R., Brisson, J., 2009. Effect of artificial aeration and macrophyte species on nitrogen cycling and gas flux in constructed wetlands. Ecol. Eng. 35, 221-229.

15. Mander, Ü., Lõhmus, K., Teiter, S., Mauring, T., Nurk, K., Augustin, J., 2008. Gaseousfluxes in the nitrogen and carbon budgets of subsurface flow constructed wet-lands. Sci. Total Environ. 404, 343-353.

16. Mander, Ü., Dotro, G., Ebie, Y., Towprayoon, S., Chiemchaisri, C., Nogueira, S.F., Jamsranjav, B., Kasak, K., Truu, J., Tournebize, J., Mitsch, W.J., 2014. Greenhouse gas emission in constructed wetlands for wastewater treatment: a review. Ecol. Eng. 66, 19-35.

17. Pan, J., Yuan, F., Yu, L., Huang, L., Fei, H., Cheng, F., Zhang, Q., 2016. Performance of organics and nitrogen removal in subsurface wastewater infiltration systems by intermittent aeration and shunt distributing wastewater. Bioresour Technol. 211, 774-778.

18. Ren, Y.G., Wang, J.H., Li, H.F., Zhang, J., Qi. P.Y., Hu, Z., 2015. Nitrous oxide and methane emissions from different treatment processes in full-scale municipal wastewater treatment plants. Environ Technol. 34, 2917-2927.

19. Rai, U.N., Tripathi, R.D., Singh, N.K., Upadhyay, A.K., Dwivedi, S., Shukla, M.K., Mallick, S., Singh, S.N., Nautiyal, C.S., 2013. Constructed wetland as an ecotechnological tool for pollution treatment for conservation of Ganga river. Bioresour Technol. 48, 535-541.

20. Saggar, S., Hedley, C.B., Giltrap, D.L., Lambie, S.M., 2007. Measured and modelled estimates of nitrous oxide emission and methane consumption from a sheep-grazed pasture. Agric Ecosyst Environ. 122, 357-365.

21. Saumya, S., Akansha, S., Rinaldo, J., Jayasri, M.A., Suthindhiran, K., 2015. 
Construction and evaluation of prototype subsurface flow wetland planted with Heliconia angusta for the treatment of synthetic greywater. J. Clean. Prod. 91, 235-240.

22. Saeed, T., Sun, G., 2012. A review on nitrogen and organics removal mechanisms in subsurface flow constructed wetlands: dependency on environmental parameters, operating conditions and supporting media. J. Environ. Manage. 112, 429-448.

23. Tanner, C.C., Adams, D.D., Downes, M.T., 1997. Methane emissions from constructedwetlands treating agricultural wastewaters. J. Environ. Qual. 26, 1056-1062.

24. Van der Zaag, A.C., Gordon, R.J., Burton, D.L., Jamieson, R.C., Stratton, G.W., 2010. Greenhouse gas emissions from surface flow and subsurface flow con-structed wetlands treating dairy wastewater. J. Environ. Qual. 39, 460-471.

25. Vymazal, J., 2011. Constructed Wetlands for Wastewater Treatment: Five Decades of Experience. Environ. Sci. Technol., 45, 61-69.

26. Vymazal J., 2014. Constructed wetlands for treatment of industrial wastewaters: A review. Ecol. Eng. 73, 724-751.

27. Wu, J., Zhang, J., Jia, W., Xie, H., Gu, R.R., Li, C., Gao, B., 2009. Impact of $\mathrm{COD} / \mathrm{N}$ ratio on nitrous oxide emission from microcosm wetlands and their performance in removing nitrogen from wastewater. Bioresour. Technol.100, 2910-2917.

28. Wu, H., Zhang J., Li P., Zhang, J., Xie, H., Zhang, B., 2011. Nutrient Removal in Constructed Microcosm Wetlands for Treating Polluted River Water in northern China. Ecol. Eng. 37, 560-568.

29. Wu, H., Zhang, J., Ngo H.H., Guo W., Hu Z., Liang S., Fan J., Liu H., 2015. A 
review on the sustainability of constructed wetlands for wastewater treatment: Design and operation, Bioresour. Technol.175, 594-601.

30. Wu, H., Fan, J., Zhang, J., Ngo, H., Guo, W., Liang, S., Lv, J., Hu, Z., Lu, S., Wu, W., Wu, S., 2016. Intensified organics and nitrogen removal in the intermittent aerated constructed wetland using a novel sludge-ceramsite as substrate, Bioresour. Technol. doi: 10.1016/j.biortech.2016.01.051.

31. Zhang, J.B, Song, C.C., Yang, W.Y., 2005. Cold season $\mathrm{CH}_{4}, \mathrm{CO}_{2}$ and $\mathrm{N}_{2} \mathrm{O}$ fluxes from freshwater marshes in northeast China. Chemosphere. 59, 1703-1705.

32. Zhao, Z., Chang, J., Han, W., Wang, M., Ma, D., Du, Y., Qu, Z., Chang, S., Ge, Y., 2016. Effects of plant diversity and sand particle size on methane emission and nitrogen removal in microcosms of constructed wetlands. Ecol. Eng. 95, 390-398. 


\section{Figure Captions:}

Figure 1 Figure 1 Profile of the laboratory-scale constructed wetland (a) and photograph of the experimental constructed wetland systems (b)

Figure 2 The variation of air temperature and relative humidity during the experimental period.

Figure 3 The variation of $\mathrm{CH}_{4}$ emissions from different wetland systems (W1:

Phragmites australis, W2: Cyperus rotundus, W3: Zizania caduciflora, W4:

unplanted) during the experimental period (a), and linear regression between air temperature and $\mathrm{CH}_{4}$ emission rates (b).

Figure 4 The variation of $\mathrm{N}_{2} \mathrm{O}$ emissions from different wetland systems (W1:

Phragmites australis, W2: Cyperus rotundus, W3: Zizania caduciflora, W4:

unplanted) during the experimental period (a), and polynomial regression between air temperature and $\mathrm{N}_{2} \mathrm{O}$ emission rates (b). 

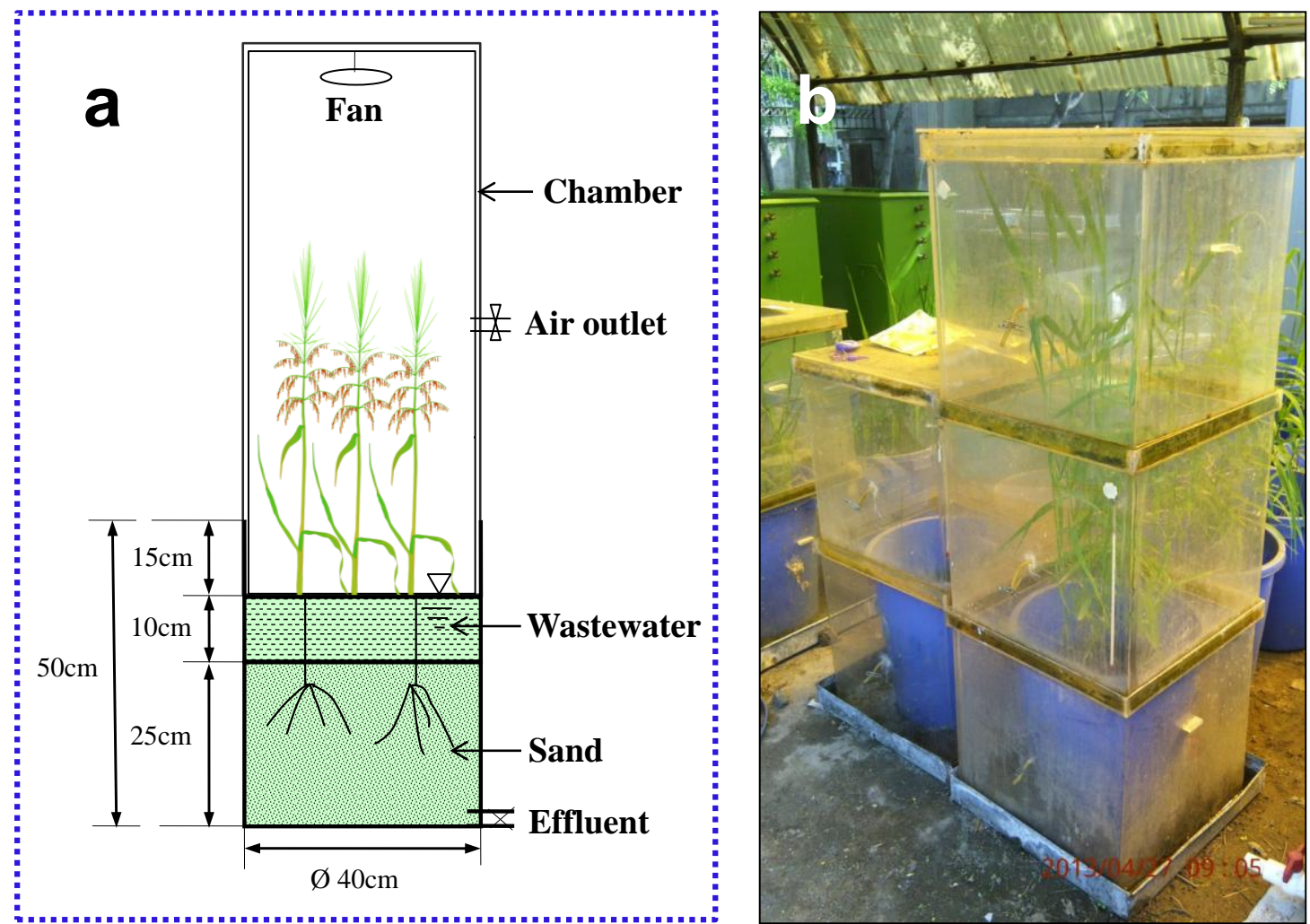

Figure 1 Profile of the laboratory-scale constructed wetland (a) and photograph of the experimental constructed wetland systems (b) 


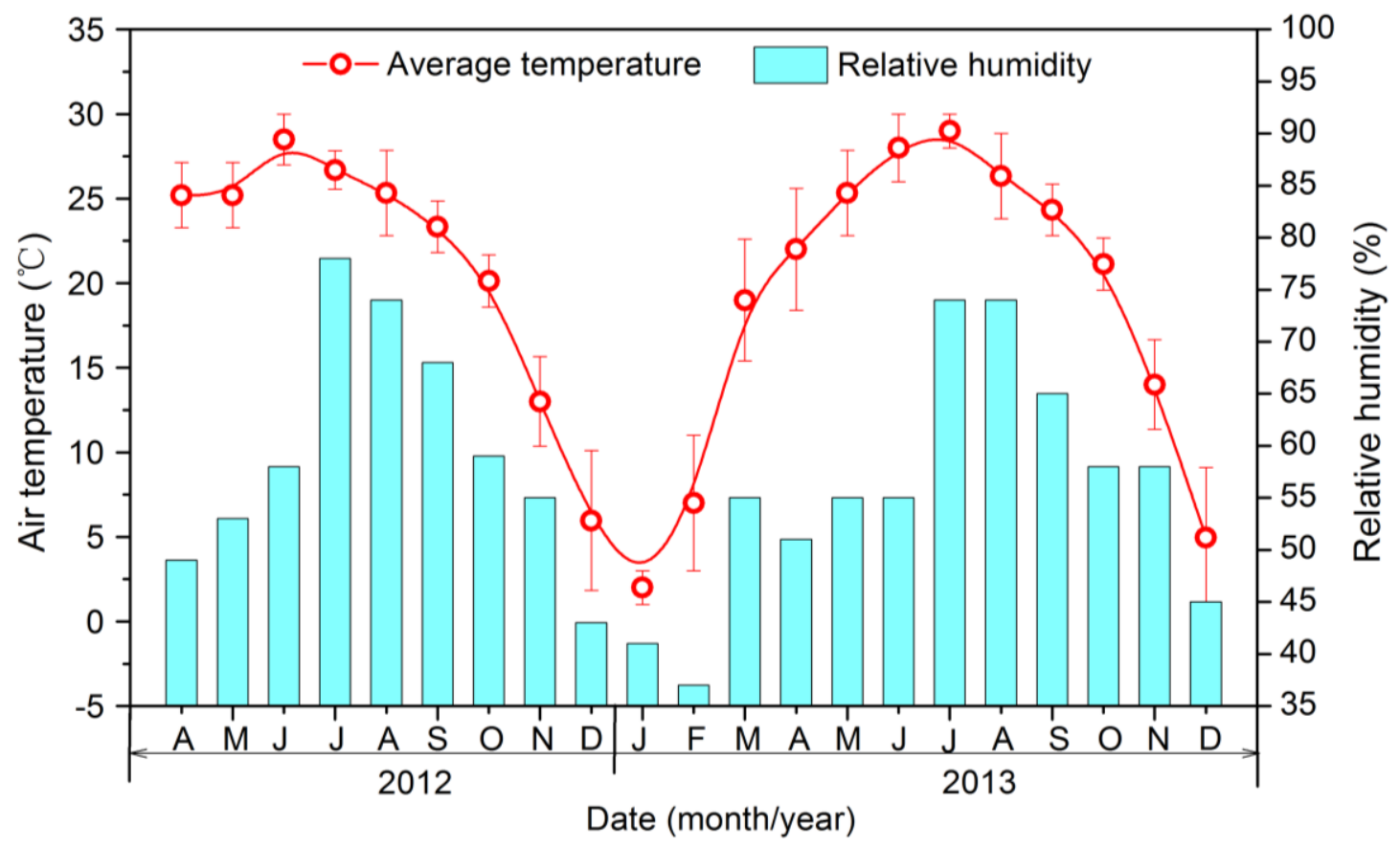

Figure 2 The variation of air temperature and relative humidity during the experimental period. 

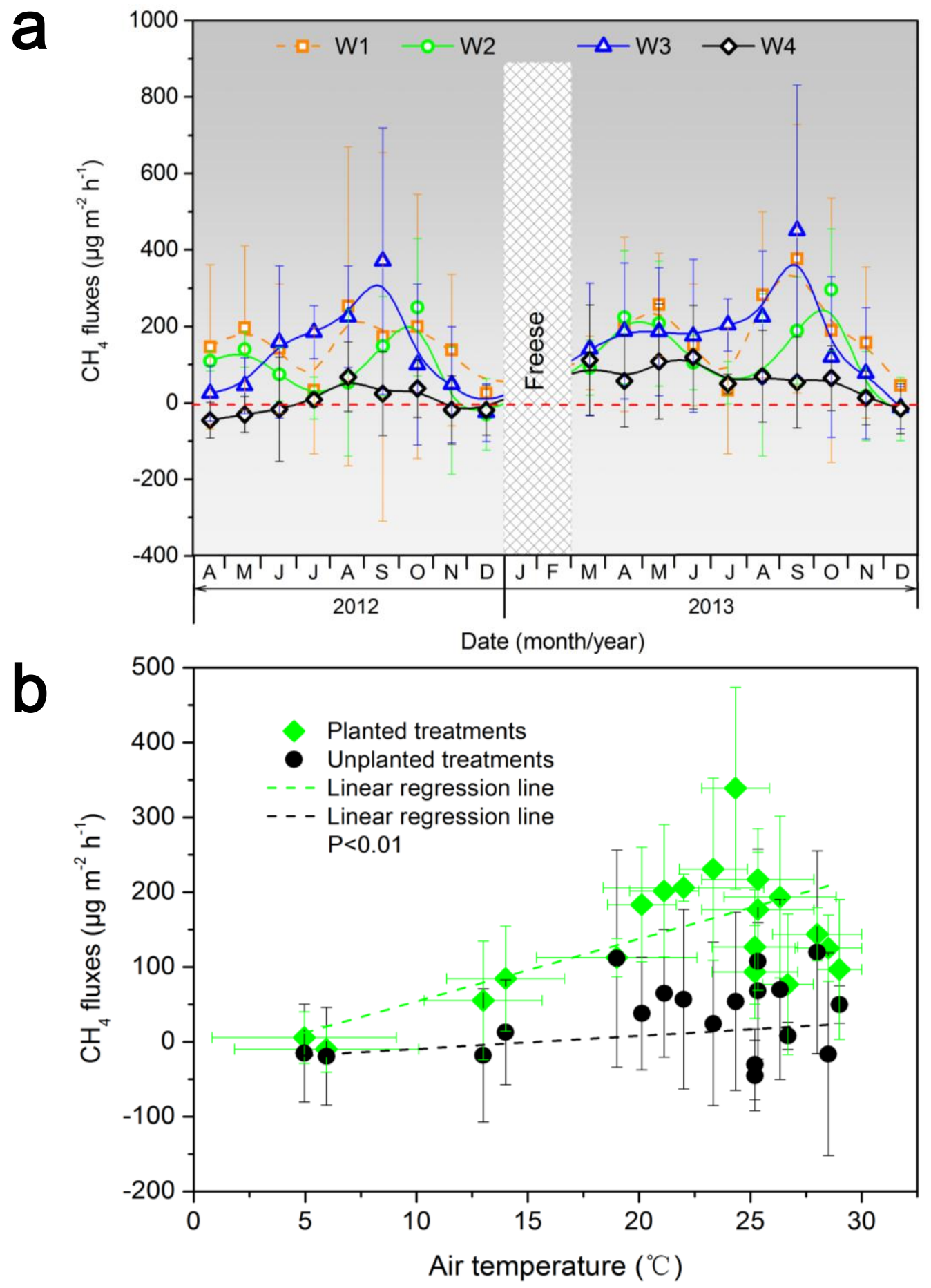

Figure 3 The variation of $\mathrm{CH}_{4}$ emissions from different wetland systems (W1: Phragmites australis, W2: Cyperus rotundus, W3: Zizania caduciflora, W4: unplanted) during the experimental period (a), and linear regression between air temperature and $\mathrm{CH}_{4}$ emission rates (b). 

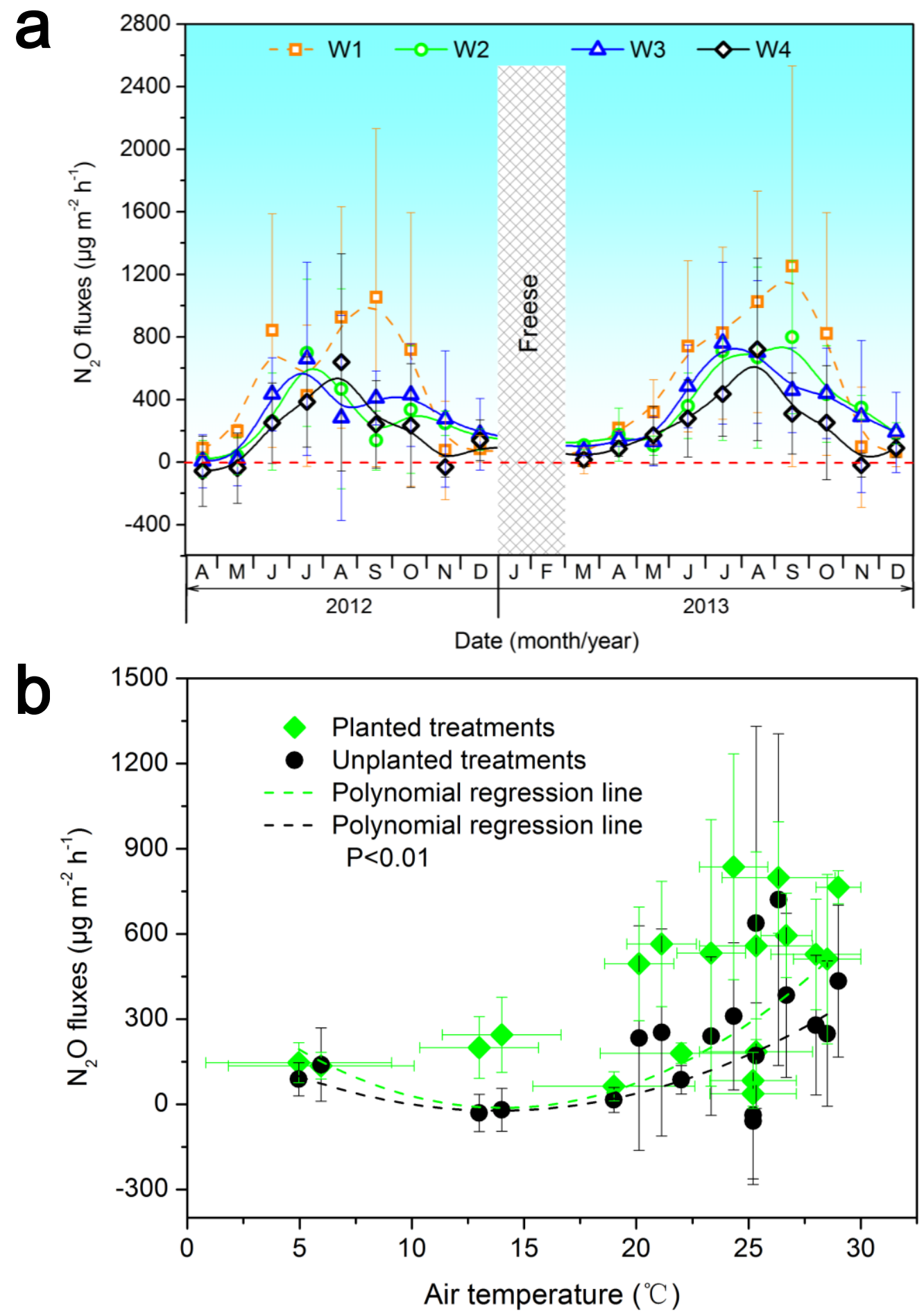

Figure 4 The variation of $\mathrm{N}_{2} \mathrm{O}$ emissions from different wetland systems (W1: Phragmites australis, W2: Cyperus rotundus, W3: Zizania caduciflora, W4: unplanted) during the experimental period (a), and polynomial regression between air temperature and $\mathrm{N}_{2} \mathrm{O}$ emission rates (b). 
